\title{
PERAN MEDIA RELATION DALAM PENYELENGGARAAN EVENT UNTUK MENINGKATKAN KINERJA DI BIDANG PUBLIC RELATIONS
}

Dewi Winarni Susyanti dan Faisal Slamet Riyadi

Jurusan Administrasi Niaga Politeknik Negeri Jakarta Kampus UI Depok 16425

email:up2m@pnj.ac.id

\begin{abstract}
ABSTRAK
Media relation is a part of public relation. It is one essential work how to build and create the good relation with media in order to inform and to prepare the event, media relation starts from how to arrange data base of event and finally asking the visitor opinion and comment by distributing the questionnaire. Media relation ask visitors and exhibitors comment or opinion during the event. They ask how the service given by the organizer during the event. Public relation officer s not only do the media relation, but he or she must $b$ able to write article, do confirmation to media, welcome media site visit and make documentation of event. Public relation must be able to formulate the public opinion. The public opinion is very important for decision maker, so that si why it is very important for them to understand and to formulate the information. The position and the activity media relation is very important, because the event is the great moment forevent organizer to promote theirself by communicating, interacting, showing and exhibiting their products. Media relation on event is very important, because the public will get the information of event from media
\end{abstract}

Key word: Media Relation, Media Relation Officer, Public Relations, Event,Database, Kuesioner, Media Cetak, Media Elektrionik, Nesw Portal, Deadline.

\section{LATAR BELAKANG}

Salah satu fungsi dan peranan yang ada dalam organisasi event adalah media relations. Media merupakan alat publikasi dan promosi paling efektif yang diperlukan event organizer untuk menjadi partner dalam menyukseskan sebuah penyelenggaraan event. Dalam membangun kerjasama dengan media, event organizer membutuhkan perwakilan yang akan menjadi penghubung antara perusahaan dengan media. Peran sebagai penghubung tersebut dilakukan oleh media relations officer.

Bekerjasama dengan media bukanlah sebuah peranan yang mudah. Dibutuhkan kemampuan berkomunikasi serta kekuatan untuk membangun hubungan yang baik untuk bisa berbicara dengan media. Memahami tujuan perusahaan sekaligus juga memahami dan melayani media adalah peran terpenting dari media relations.

Mahasiswa yang terlibat dalam kegiatan ini adalah mahasiswa yang sedang melaksanakan job training di bidang public relations di berbagai perusahaan di wilayah Jabodetabek. Hasil yang diperoleh akan dijadikan sebagai sumbangan berupa informasi dalam proses pembelajaran khususnya Public Relations, sehingga proses belajar mengajar akan semakin meningkat dan kompetensi mahasiswa di bidang public relations pun meningkat. Oleh karenanya judul kegiatan Program Research Grant: Peran Media Relation Dalam Penyelenggaraan Event Untuk Meningkatkan Kinerja di Bidang Public Relations. 


\section{PERUMUSAN MASALAH :}

Permasalahan media relation yang dirumuskan dalam Research Grant meliputi :

1 Bagaimana bentuk kegiatan media relation dalam penyelenggaraan sebuah event?.

2 Bagaimana strategi media relation untuk meraih dukungan publik dalam penyelenggaran sebuah event?.

3 Hal apa saja yang dilakukan public relations agar mampu mengatasi persoalan dalam hubungannya dengan media ?.

Dengan mengetahui bentuk kegiatan, strategi dan hambatan yang berasal dari publik media, maka akan mempengaruhi kinerja public relations. Oleh karenanya perlu diketahui bagaimana upaya praktisi public relations menghadapi tantangan tersebut untuk meraih dukungan publik agar penyelenggaraan event berjalan dengan lancar dan sukses.

\section{TINJAUAN PUSTAKA}

Menurut SK Menteri Parpostel No. KM. 108/HM.703/MMPT-01 Pasal.1, menyatakan bahwa Konferensi atau Konvensi, Kongres adalah suatu kegiatan berupa pertemuan sekelompok negarawan, usahawan, cendekiawan, dan sebagainya untuk membahas masalah yang berkaitan dengan kepentingan bersama. Dalam suatu event, selain kegiatan kongres diselenggarakan pula sebuah pameran atau yang diistilahkan sebagai Expo. Expo merupakan kata yang sering digunakan untuk menggambarkan kegiatan pameran yang diselenggarakan secara berkala. Definisi umum yang seringkali diberilkan kepada exhibition (pameran) adalah ' 'Event at which products and services are displayed'. Goldbald (1997) memberikan penjelasan mengenai exhibition sebagai sebuah aktivitas yang didisain bagi sasaran shareholder atau suplier product, peralatan dan pelayanan untuk mendemonstrasikan dan mempromosikan produk mereka ke pasar.

Pameran memungkinkan terjadinya komunikasi langsung dengan pihak konsumen, tersedianya informasi dan tukar menukar informasi mengenai suatu produk atau jasa yang bisa mempengaruhi keputusan pembelian dan atau penguatan merek suatu produk/jasa. Pameran merupakan event masyarakat yang diselenggarakan oleh suatu organisasi independen dan terbuka untuk umum (Lidia Evelina, 2005 :4).

Frank Jefkins (2004) menyatakan, bahwa tugas dan fungsi utama PRO atau pejabat humas tidak terlepas dari bidang informasi dan komunikasi mengenai kegiatan (aktivitas) perusahaan yang diwakilinya, untuk disampaikan kepada komunikan (publik) sebagai sasaran atau targetnya. Menurut Rosady (200:90), pihak public relations menitikberatkan segi "publisitas" (publicity). Penyampaian berita dalam garis besarnya lebih menonjolkan hal-hal yang berbau sensasional dan menarik perhatian pembaca, menonjolkan peristiwa tertentu (event), pertentangan (conflict), dan ide atau info terbaru (new idea and information).

Barbara Averill (1997), menyatakan bahwa, media relations hanyalah salah satu bagian dari public relations, namun ini bisa menjadi perangkat yang sangat penting dan efisien. Istilah yang umum dipergunakan untuk hubungan dengan media adalah 
press relations atau hubungan pers. Istilah pers sendiri juga sering diidentikkan dengan media cetak. Bahkan banyak kegiatan dalam media relations menekankan betul pada penjalinan hubungan baik dengan media cetak tersebut. Seiring dengan perkembangan media dan juga praktik PR, istilah yang paling tepat dipakai adalah media relations atau hubungan media.

Seperti yang dikemukakan di muka, public relations, sesuai dengan tujuan utamanya, akan dituntut untuk mengembangkan atau membangun hubungan yang baik, tidak hanya dengan pihak internal, tetapi juga termasuk dengan berbagai pihak luar atau kalangan yang terkait (external relations), salah satunya dengan pihak media. Berkomunikasi dengan media sangatlah dibutuhkan dalam kegiatan penyelenggaraan event. Berbagai cara yang dapat dilakukan adalah dengan menyediakan press kit untuk media pemberitaan, mengenal dengan baik orang-orang yang bekerja pada media pemberitaan, menyebarkan siaran pers ketika kegiatan/peristiwa terjadi, dan menindaklanjuti hubungan dengan media pemberitaan.

Dalam kegiatan berkomunikasi dengan media, hal teknis yang perlu dikuasai PR adalah ketrampilan menulis siaran pers (press release), membuat laporan liputan media atau mendokumentasikan kegiatan. Sedangkan analisis yang merupakan pekerjaan yang membutuhkan kemampuan intelenjensia, seperti mengkaji opini publik, membaca kecenderungan atau merumuskan permasalahan berdasarkan berbagai data yang dimiliki (Yosal Iriantara, $2005: 13$ ).

Menurut Rachmady (2004:88) dan Anggoro (2000:76), kegiatan yang dikelola praktisi PR mengandung sejumlah penting yang memiliki implikasi manajerial bagi diri pribadi dan tim. Terdapat sejumlah elemen dasar, seperti hubungan media dan kegiatan-kegiatan yang bersifat membina relasi dari waktu ke waktu dengan tujuan tertentu. Dan, sebagai praktisi PR, tugas dan tanggungjawab PRO/pejabat humas adalah menciptakan kepercayaan, kejujuran dalam memberikan informasi dan publikasi yang baik kepada masyarakat, yang didukung dengan kiat dan teknik-teknik tertentu untuk memperoleh citra bagi perusahaan yang diwakilinya.

\section{TUJUAN DAN MANFAAT PENELITIAN}

\section{TUJUAN PENELITIAN}

Dengan membina hubungan yang sangat sederhana sekalipun hubungan dengan pers sudah dapat terbina. Buat mereka yang berkecimpung di bidang event, praktisi PR harus bekerja untuk dapat menarik perhatian media, mereka membutuhkan kemampuan prima dan harus memiliki kiat-kiat dan strategi yang bagus untuk meraik perhatian wartawan dan medianya. Kalau tidak, meski acara yang digelar bernilai berita, jumlah wartawan yang hadir sangat sedikit. Sehingga dalam pelaksanaannya praktisi PR perlu melakukan banyak komunikasi, baik komunikasi langsung secara personal contact, maupun komunikasi melalui media massa. Namun banyak pula hambatan yang dialami praktisi PR dalam menjalani kegiatannya tersebut, sehingga kegiatan research grant bertujuan untuk:

1 Mengetahui bentuk kegiatan media relation dalam penyelenggaraan sebuah event?.

2 Mengetahui strategi media relation untuk meraih dukungan publik dalam penyelenggaran sebuah event?. 
3 Menerapkan hal apa saja yang dilakukan public relations agar mampu mengatasi persoalan dalam hubungannya dengan media?.

\section{LUARAN YANG DIHARAPKAN :}

Melalui kegiatan ini diharapkan mahasiswa yang melakukan job training akan mampu menggali dan mengenali bagaimana strategi meraih dukungan publik melalui media relation, terutama dalam berkomunikasi dan menghadapi hambatan-hambatan dari publik media.

Di sisi lain, semua hasil penelitian tersebut perlu dituangkan dalam proses belajar mengajar dan penyusunan materi berbasis komptensi. Hal ini tentunya akan menjadi khasanah atau penambah sumbangan berupa informasi bagi kemajuan ilmu Public Relations. Di samping itu akan memperkaya materi Media Relation serta meningkatkan mahasiswa agar lebih kompeten dalam bidang Public Relations.

\section{MANFAAT PROGRAM :}

1 Penelitian ini sangat berguna untuk memberi sumbangan berupa informasi yang berguna bagi kemajuan ilmu pengetahuan, sekaligus mengembangkan materi public relations di dalam proses belajar-mengajar, karena :

2 Pengetahuan yang diperoleh di lapangan merupakan pengalaman langsung $\mathrm{PRO}$ /pejabat humas, sehingga sangat bermanfaat untuk memperkaya wawasan ke-PR-an di dalam proses belajar mengajar.

3 Materi media relation dapat dikembangkan sesuai dengan kompetensi yang dibutuhkan di bidang public relations.

\section{METODE PENELITIAN}

Menurut Dedi (2001:67) Untuk menjawab pertanyaan penelitian pada tujuan penelitian maka peneliti menggunakan paradigma kualitatif. Bogdan dan Taylor (dalam Moleong,2000:3) mendefinisikan metode penelitian kualitatif sebagai prosedur penelitian yang menghasilkan data deskriptif berupa kata-kata tertulis atau lisan dari orang dan perilaku yang dapat diamati. Dalam hal ini mahasiswa sebagai surveyor melakukan pengamatan terhadap praktisi PR di berbagai industri/perusahaan untuk menggambarkan secara tepat sifat-sifat suatu individu dan keadaannya serta mencatatnya dalam tulisan.

\section{Teknik Pengambilan Data}

Dalam pengambilan data, mahasiswa menggunakan pendekatan eksploratif dan kualitatif. Menurut Jalaludin (1997:53), pendekatan eksploratif dipergunakan untuk mendapatkan gambaran yang menyeluruh tentang kegiatan praktisi public relations terhadap publik internal dan publik eksternalnya, serta hambatan-hambatan yang ditimbulkannya. Kemudian bagaimana kiat dan strategi PRO pejabat humas dalam mengatasi situasi dan persoalan tersebut.

\section{Tempat dan Waktu Penelitian}

Adapun yang menjadi tempat penelitian ini adalah industri/perusahaan yang tersebar di wilayah Jabodetabek yang menjadi tempat mahasiswa melakukan job training dalam rangka menyusun tugas akhirnya. Sedangkan waktu pelaksanaan 
penelitian ini dilakukan selama empat bulan mulai dari persiapan bahan-bahan, penyusunan pedoman wawancara, pelaksanaan wawancara, pengkajian bahan-bahan yang akan diteliti serta pengolahan dan analisa data.

\section{Obyek Penelitian}

Kegiatan-kegiatan public relations yang dirancang oleh praktisi PR sangat beragam dan membutuhkan kreativitas. Di samping itu praktisi PR harus pula melakukan pendekatan yang spesifik terhadap media agar kegiatan peliputan berita ke publiknya bisa berjalan lancar, sehingga peran praktisi PR disini dituntut sebaik dan sesempurna mungkin demi terjalinnya keharmonisan hubungan antara public relations dengan media, baik cetak maupun media elektronik. Dengan demikian yang menjadi obyek penelitian disini adalah para mahasiswa yang sedang melakukan job training di berbagai perusahaan event pada saat event tersebut sedang berlangsung.

\section{Analisa Data}

Dalam melakukan analisis data saat pengumpulan data, peneliti menggunakan alat yang dapat memastikan agar data tersebut layak untuk dipercaya kebenarannya, yakni Triangulasi (Deddy, 2001 :74). Dengan metode Triangulasi ini, peneliti mencari beberapa sumber berbeda yang dapat memberikan pandangan serta masukan-masukan penting tentang situasi yang mirip dan berhubungan satu sama lain, terutama dalam mengelola kegiatan media relations. Dengan membanding data yang diperoleh dengan sumber-sumber lain akan meyakin data yang sudah didapat. Penggunaan berbagai sumber yang berbeda adalah untuk mendukung hasil yang didapat juga memungkinkan peneliti untuk dapat mendeskripsikan temuan ini agar lebih akurat dan meyakinkan.

\section{HASIL PENELITIAN DAN PEMBAHASAN}

\section{PERAN MEDIA RELATION DALAM EVENT THE $1^{\text {st }}$ ASIAN FITNESS AND HEALTH CONFERENCE \& EXPO 2008 (AFHCE-2008)}

Event The $1^{\text {st }}$ Asian Fitness and Health Conference \& Expo 2008 (AFHC-2008) adalah konferensi yang dibuat untuk kalangan fitness dan kesehatan guna membahas isu-isu terbaru di industrinya. Event tersebut diselenggarakan oleh International Fitness Profesional Association (IFPA) yang berbasis di Miami, Florida, Amerika Serikat. Konferensi mengenai fitness dan kesehatan seperti ini diselenggarakan setiap tahun secara anual di Amerika Serikat.

Pada bulan Februari 2008, James T. Bell, CEO IFPA datang ke Indonesia untuk menjadi pembicara dalam sebuah anti-aging course di Jakarta. Kemudian lahirlah ide untuk membuat konferensi fitness pertama di luar Amerika. Penyebabnya adalah industri fitness di negara-negara luar Amerika telah berkembang semakin pesat bahkan sudah menjadi gaya hidup sebagian besar masyarakat perkotaan.

The $1^{\text {st }}$ Asian Finess and Health Conference \& Expo 2008 dengan tema The First Breaking Coference \& Expo for The Asian Fitness and Health Industry ini dilaksanakan pada tanggal 17-19 Oktober 2008 di Balai Kartini Convention and Exhibition Center Jakarta. Agenda yang dilaksanakan dalam event ini adalah: conference, exhibition dan certification course. 
Conference dihadiri oleh 200 orang peserta yang terdiri dari para pelaku industri fitness dan dokter. Exhibition diikuti oleh 14 exhibitor termasuk sponsor dan media partner. Certification course diikuti oleh 25 orang profesional fitness trainer yang menjadi anggota IFPA Indonesia.

AFHCE-2008 didukung oleh Departemen Kebudayaan dan Pariwisata, Kementerian Pemuda dan Olahraga, Pemda DKI Jakarta, Federasi Olahraga Masyarakat Indonesia (FOMI), Bhakti Husada, INCCA, ASPERAPI, serta 12 media partners dan 23 strategic partners lainnya dengan sponsor utama L-MEN susu khusus pria yang diproduksi oleh PT. Nutrifood Indonesia.

\section{PERAN MEDIA RELATION}

Persiapan yang dilakukan media relation officer dalam meneyelenggarakan event terbagi atas dua tahap :

1. Persiapan Bulan Pertama :

Kegiatan bulan pertama dari persiapan AFHCE sejak bulan Agustus sampai dengan bulan September 2008. Dalam masa persiapan tersebut, media relations officer melakukan kegiatan antara lain :

a. Mengumpulkan Database

Kegiatan mengumpulkan database adalah kegiatan yang dilakukan untuk mencari keterangan mengenai media yang terbit baik secara lokal, nasional maupun regional. Keterangan tersebut meliputi informasi-informasi yang dibutuhkan untuk dapat berhubungan dengan pihak redaksi media.

Tugas media relation officer dalam AFHCE-2008 secara khusus adalah mengumpulkan database media untuk digunakan sebagai pedoman dalam menentukan media partners. Kegiatan pengumpulan database media ini memerlukan waktu selama seminggu. Proses pengumpulan database dilakukan dengan cara menelusuri internet, yellow pages, directory, dan email-email yang diperoleh dari hasil networking dengan rekan-rekan media dan public relations.

Lima jenis media yang berhasil dukumpulkan adalah : koran, majalah, televisi, radio dan news portal, dengan rincian sebagai berikut :

\begin{tabular}{|l|l|}
\hline Kategori Media & Jumlah Database \\
\hline Majalah & 310 \\
\hline Koran & 176 \\
\hline Televisi & 14 \\
\hline Radio & 261 \\
\hline News Portal & 3 \\
\hline
\end{tabular}

Penting bagi media relation officer untuk memiliki pemahaman tentang media, karena hal ini akan membantu peran media dalam menentukan rekanan media (media partners) yang meliputi :

1) Profil Media 
Profil media setidaknya berisi nama media, alamat redaksi, nama pemimpin redaksi/project officer, nomor telepon dan faksimili, serta contact person yang dapat dihubungi jika akan melakukan kerjasama dengan media.

2) Harga Iklan dan Advetorial

Salah satu bentuk kerjasama yang sering dilakukan dengan media adalah pemasangan iklan ataupun advetorial. Untuk itu media relations officer harus memiliki daftar harga iklan dan advetorial media agar dapat menentukan kesepakatan kerjasama yang sesuai.

3) Kebijakan Editorial

Kebijakan editorial merupakan pandangan dasar dari suatu media yang dengan sendirinya akan melandasi pemilihan subjek-subjek yang akan dicetak atau yang akan diterbitkan.

4) Frekuensi Penerbitan

Setiap terbitan memiliki frekuensi penerbitan yang berbeda-beda. Ada yang terbit setiap hari, dua kali seminggu, mingguan, dua mingguan, bulanan, tiga bulanan, atau bahkan tahunan. Jumlah edisi yang diterbitkan dalam satu kali penerbitan (oplag) juga perlu diketahui.

5) Tanggal Terbit

Tanggal terbit dan tenggat waktu (deadline) sebuah materi diterima oleh redaksi untuk diterbitkan pada suatu edisi juga harus diketahui oleh media relation officer.

6) Daerah Sirkulasi

Jangkauan sirkulasi dari sebuah media, ada yang berskala lokal, khusus di pedesaan, perkotaan, berskala nasional ataupun regional.

7) Jangkauan Pembaca

Media relation officer harus memiliki data mengenai kelompok usia, jenis kelamin, pekerjaan, status sosial, minat khusus, etnik, agama, hingga ke orientasi politik dri khalayak suatu media.

8) Metode Distribusi

Media relation officer juga perlu mengetahui metode distribusi dari suatu media, apakah melalui toko-toko buku, penjajakan dari pintu ke pintu ke pengiriman, sistem langganan atau secara terkontrol yaitu pengiriman berdasarkan permintaan dan seleksi.

9) Klasifikasi Media

Salah satu karakteristik media ialah memiliki khlayak sendiri yang memiliki perbedaan status sosial-ekonomi. Media relation officer harus memahami klasifikasi ini untuk dapat menentukan target media partner yang sesuai dengan target peserta event. Berikut ini adalah klasifikasi media berdasarkan status sosial- ekonomi khalayaknya :

\begin{tabular}{|l|l|}
\hline Klasifikasi & Status Sosial-Ekonomi \\
\hline A & Kelas menengah ke atas \\
\hline B & Kelas menengah \\
\hline C & Kelas menengah ke bawah \\
\hline D & Kelas pekerja \\
\hline
\end{tabular}


Keterangan lengkap yang diperoleh selama masa pengumpulan database akan memudahkan proses kerja media relation officer saelanjutnya, yaitu memilih media partner yang sesuai dan representatif untuk event yang akan diselenggarakan.

\section{MEMILIH MEDIA PARTNER}

Media partner adalah bentuk kerjasama yang sangat efisien dalam penyelenggaraan sebuah event, hal ini disebabkan karena apabila sebuah acara dipublikasikan lewat media maka hal tersebut akan dikonsumsi oleh masyarakat secara luas. Sehingga informasi yang hendak disampaikan bisa secara serentak diterima oleh khalayak ramai tanpa perlu membuang waktu dan sumber daya yang lebih untuk mengulang-ulang pemberitaan person to person.

Media partner tidak didapatkan dengan cara random, melainkan dibutuhkan proses pemilihan yang tepat oleh media relation officer. Dari ribuan database media yang didapatkan, hanya dipilih sejumlah media yang tepat dan sesuai dengan event untuk dikirimkan surat penawaran kerjasama.

Target peserta AFHCE-2008 adalah masyarakat dengan status sosial ekonomi menengah dan menengah ke atas. Hal ini disebabkan oleh harga kepesertaan yang dikenakan cukup tinggi. Selain itu, fitness di Indonesia sendiri memang masih tersegmentasi pada masyarakat kalangan atas, karena biaya pelatihannya yang mahal.

Hal inilah yang juga disesuaikan dalam memilih media partner. Media relation officer tidak mungkin memilih media partner dari media dengan klasifikasi $\mathrm{C}$ ataupun $\mathrm{D}$ yang memiliki khalayak pembaca berstatus sosial ekonomi menengah ke bawah untuk sebuah event dengan target peserta menengah ke atas. Maka media partner yang sesuai untuk event AFHCE-2008 adalah media dengan klasifikasi B dan A yang memiliki khalayak pembaca dari status sosial ekonomi menengah dan menengah ke atas.

Khusus untuk media majalah, pertimbangan yang dilakukan tidak hanya berdasarkan klasifikasi khlayak media, namun juga berdasarkan segmentasi majalah itu sendiri.

Berbeda halnya dengan televisi, koran, radio, dan news portal yang biasanya memberikan informasi bersifat umum kepada masyarakat, majalah biasanya tersegmentasi berdasarkan tema tertentu, misalnya majalah olahraga, majalah ibu dan anak, majalah wanita, majalah fashion, dan sebagainya. Agar sesuai dengan AFHCE2008, majalah dijadikan target media partner adalah majalah dengan tema fitness dan kesehatan.

Berdasarkan pertimbangan-pertimbangan tersebut didapati bahwa tidak semua media yang ada di dalam database sesuai untuk dijadikan media partner. Untuk itu, media relation officer harus bisa menentukan media mana saja yang sesuai untuk diajak bekerjasama. Dari hasil pemilihan secara seksama, diperolehlah statistik perbandingan antara database media yang didapat dengan jumlah media yang sesuai untuk dijadikan media partner. Berikut ini perbandingannya:

\begin{tabular}{|l|l|l|}
\hline Kategori Media & Jumlah Database & Sesuai sebagai media partner \\
\hline Majalah & 310 & 65 \\
\hline
\end{tabular}




\begin{tabular}{|l|l|l|}
\hline Koran & 176 & 12 \\
\hline Televisi & 14 & 14 \\
\hline Radio & 261 & 6 \\
\hline News Portal & 3 & 3 \\
\hline Total & $\mathbf{7 6 4}$ & $\mathbf{1 0 0}$ \\
\hline
\end{tabular}

\section{PENGIRIMAN SURAT PENAWARAN KERJASAMA}

Peran dari media relation officer selanjutnya ialah membuat dan mengirimkan surat penawaran kerjasama kepada redaksi media yang telah didaftar sebagai media yang sesuai untuk menjadi media partner. Surat penawaran harus dibuat dengan cara yang ringkas namun jelas, sehingga pihak media yang menerima bisa langsung menangkap maksud dari surat tersebut. Hal yang harus dimasukkan dalam surat penawaran ialah :

1. Perkenalan diri

2. Perkenalan perusahaan (PCO)

3. Perkenalan event (secara singkat)

4. Tawaran bekerjasama

Banyaknya jumlah media yang akan dikirimkan surat penawaran kerjasama membuat kerja media relation officer cukup sibuk. Namun, dengan bantuan teknologi, pekerjaan media relations ini bisa dibuat menjadi lebih mudah. Pengiriman surat penawaran kerjasama dapat dilakukan melalui email yang hanya membutuhkan waktu sebentar dan tidak perlu dilakukan pengetikan surat berulang-ulang karena format surat yang ada tinggal di copy-paste lalu dikirimkan ke alamat email redaksi media. Untuk beberapa media yang alamat email redaksinya tidak didapatkan selama proses pengumpulan database, surat penawaran kerjasama dikirimkan melalui faksimili.

Setelah pengiriman surat penawaran kerjasama, media relation officer harus melakukan konfirmasi kepada pihak media, untuk memastikan bahwa redaksi telah menerima surat penawaran kerjasama yang dikirimkan.

\section{KONFIRMASI AWAL}

Konfirmasi untuk mengetahui status surat penawaran dilakukan lewat telepon. Ketika konfirmasi dilakukan, media relation officer menerima bermacam-macam respon dari media. Berikut ini adalah contoh kasus yang terjadi di lapangan, ketika penulis melakukan konfirmasi awal terhadap calon media partner :

1. Redaksi yang diajak bicara merasa tidak tahu menahu mengenai perihal surat penawaran kerjasama tersebut. Tindakan yang dilakukan media relations adalah meminta berbicara kepada bagian marketing ataupun divisi lain yang bertanggung jawab untuk masalah partnership. Setelah disambungkan dengan pihak yang bersangkutan, ternyata pihak tersebut tidak merasa pernah menerima surat penawaran kerjasama baik dalam bentuk faksimili maupun email, dan meminta untuk dikirimkan surat penawaran ulang. Hal ini bisa disebabkan oleh alamat email ataupun nomor faksimili yang tidak valid sehingga surat penawaran tersebut tidak sampai, ataupun sudah sampai namun diterima oleh pihak yang tidak tepat sehingga tidak disampaikan kepada pihak yang seharusnya. Menanggapi hal tersebut, media relations meminta alamat email maupun nomor faksimili yang valid serta nama contact person yang tepat, sehingga surat penawaran yang akan 
dikirimkan ulang bisa dipastikan sampai dan mendapat tanggapan dari pihak yang tepat.

2. Redaksi sudah menerima surat penawaran yang dikirimkan, namun belum bisa mengambil keputusan karena masih dalam beberapa pertimbangan dan menunggu diposisi dari pihak pimpinan. Redaksi kemudian meminta untuk dihubungi kembali pada minggu yang akan datang.

3. Sama seperti kasus nomor 2 di atas, namun redaksi meminta tidak perlu dihubungi kembali karena pihak mereka akan menghubungi jika memang tertarik untuk bekerjasama.

4. Redaksi sudah menerima surat penawaran dan tidak berniat untuk bekerjasama dengan berbagai alasan sehingga menutup kemungkinan untuk bernegosiasi.

5. Redaksi belum menerima surat penawaran dan tidak minta dikirimkan kembali karena tidak ingin menjadi media partner untuk event fitness maupun kesehatan.

6. Redaksi pindah kantor dan tidak diketahui alamat barunya.

7. Nomor yang dihubungi salah sehingga tidak dapat memperoleh informasi apa-apa.

8. Media sudah tidak beroperasi lagi.

Dari tahap konfirmasi awal ini, media relations memperoleh data yang baru. Dimana jumlah media yang masih harus tetap dikonfirmasi semakin mengecil, karena sebagian media sudah menolak bekerjasama serta ada pula beberapa media yang sudah tidak beroperasi lagi.

\section{KONFIRMASI AKHIR}

Satu minggu setelah konfirmasi awal, media relations harus melakukan konfirmasi ulang untuk memperoleh jawaban dari pihak media yang telah menerima surat penawaran kerjasama. Pada tahapan ini, media relation officer harus mampu melakukan negosiasi dan memberikan penjelasan yang lebih spesifik kepada media. Hal ini dibutuhkan intuk mempengaruhi keputusan media sesegera mungkin.

Oleh karena waktu persiapan yang tidak panjang, maka media relation officer tidak boleh menghabiskan waktu terlalu banyak untuk terus-menerus melakukan kontak dengan media-media yang tidak memberikan respon yang antusias. Untuk itu, media relations hanya akan berkonsentrasi untuk melobi media-media yang benar-benar potensial dan memiliki prospek kerjasama. Untuk menilai propek ini, media relations officer harus jeli melihat tanggapan yang diberikan redaksi media ketika melakukan konfirmasi. Dari pembicaraan di telepon, media relation officer harus sudah bisa menentukan media mana saja yang memang benar-benar berminat dan media mana yang hanya mengulur-ulur waktu tanpa memberi kepastian.

Tahap konfirmasi harus segera bergerak ke tahap ksepakatan kerjasama. Hal yang dibutuhkan media relation officer pada tahpan ini ialah target. Baik kuantitas maupun kualitas. Kuantitas media yang menjadi dan kualitas media itu sendiri, yakni media yang representatif untuk sebuah event berkelas regional.

Dihabiskan waktu satu minggu untuk melakukan kontak secara intens dengan beberapa media yang menjadi target partner dalam AFHCE-2008. Hasil yang diperoleh dari proses ini adalah lima media bersedia untuk menjadi media partner. Kelima media tersebut ialah.

1. Healthy Life

2. Health $n$ Tourism 


\section{Health Today}

4. Financial Wealth

5. South Jakarta

Pada tahap awal persiapan event ini dilakukan sebelum penulis terlibat sebagai media relation officer, telah didapatkan pula tujuh media partner lain yang keseluruhan proses negosiasi awalnya dilakukan sendiri oleh project director, sehingga penulis yang berperan sebagai media relations kemudian hanya melanjutkan tugas sesuai dengan kesepakatan awalyang telah dibuat oleh project director dan media partner tersebut.

Jadi, secara keseluruhan event AFHCE-2008 memiliki 12 media partner yang semuanya ialah media majalah. Berikut daftar media partner yang diperoleh :

\begin{tabular}{|l|l|l|}
\hline Media Partner & Group & Jangkauan Distribusi \\
\hline Venue & - & Nasional : seluruh Indonesia \\
\hline Men's Health & Femina & Nasional : seluruh Indonesia \\
\hline Fit & Femina & Nasional : seluruh Indonesia \\
\hline Fitness & MRA & Nasional : seluruh Indonesia \\
\hline Men's Fitness & MRA & Nasional : seluruh Indonesia \\
\hline Good Housekeeping & MRA & Nasional : seluruh Indonesia \\
\hline Cosmopolitan & MRA & Nasional : seluruh Indonesia \\
\hline Health Tourism & - & Nasional : seluruh Indonesia \\
\hline Healthy Life & - & Nasional : seluruh Indonesia \\
\hline Health Today & & Nasional : seluruh Indonesia \\
\hline Finance Wealth & & $\begin{array}{l}\text { Regional : Asia Tenggara, Cina, Hongkong, } \\
\text { Jepang }\end{array}$ \\
\hline South Jakarta & & Jakarta Selatan dan sekitarnya \\
\hline
\end{tabular}




\section{PERAN MEDIA RELATIONS DALAM EVENT INDO DEFENCE \& AEROSPACE 2008 EXPO \& FORUM (IDA 2008) OLEH PT NAPINDO MEDIA ASHATAMA}

Peran media relations officer adalah melaksanakan promosi periklanan setelah adanya penetapan perencanaan. Perencanaan dalam promosi periklanan merupakan faktor yang menuntun kepada keberhasilan pelaksanaan event yang akan dicapai. Pedoman pelaksanaan promosi pun didasarkan pada jadwal pelaksanaan promosi iklan pada event Indo Defence \& Aerospace 2008 Expo \& Forum (IDA 2008) yang telah dibuat. Berdasarkan data tersebut pelaksanaan promosi iklan IDA 2008 oleh PT Napindo Media Ashatama mencakup pada kegiatan sebagai berikut :

1. Penyusunan Daftar Pengunjung event IDA 2008

Pameran IDA 2008 yang bersifat business to business membuat pihak PT Napindo Media Ashatama membuat segmentasi pengunjung. Dalam menyesuaikan target pengunjung dengan sifat pameran IDA 2008, Departemen Research and Development melakukan pengumpulan daftar pengunjung selama delapan bulan sebelum event dengan langkah-langkah sebagai berikut :

1) Mengumpulkan Database Calon Pengunjung

Database calon pengunjung yang menjadi sasaran pameran IDA 2008 dapat dikumpulkan berdasarkan database pengunjung event IDA 2008 pada tahun 2006 dimana pengunjung melampirkan kartu nama (business card) atau mengisi formulir registrasi/ visitor ticket yang sebelumnya telah diisi oleh pengunjung, yellow pages untuk mendapatkan data perusahaan, melalui situs internet, dan bekerjasama dengan instansi pemerintahan seperti Departemen Pertahanan, Departemen Perhubungan, dan Departemen Industri.

2) Pengolahan Data Pengunjung

Setelah data pengunjung sudah terkumpul maka bagian research and development melakukan update data calon pengunjung mengenai nama, posisi/ jabatan, nama perusahaan, alamat perusahaan, email, nomor telepon, hingga business activity perusahaan. Pembaharuan data dilakukan dengan menelepon satu per satu data pengunjung untuk pengiriman brosur dan invitation visitor. Data yang sudah lengkap kemudian dimasukkan ke dalam program database.

3) Pengiriman Brosur

Brosur untuk calon pengunjung dikirimkan secara bertahap. PT Napindo Media Ashatama melakukan pengiriman brosur dalam bentuk :

\section{a. Show Update dan Post Card}

Show Update dan Post Card dikirimkan secara bersamaan kepada pihak peserta dan calon pengunjung IDA 2008 pada minggu kedua bulan Julia atau empat bulan sebelum event berlangsung. Pada show update berisi informasi mengenai perkembangan pameran IDA 2008 yang akan berlangsung sedangkan pada post card berguna untuk memberi informasi melalui show highlights dan mengundang calon pengunjung pameran. 


\section{b. $\quad$ Show Preview dan Invitation Ticket}

Dalam hal ini show preview dikirmkan sekaligus dengan invitation ticket untuk calon pengunjung IDA 2008 yang dilakukan satu bulan sebelum event diselenggarakan. Show preview memuat keterangan mengenai peserta dan barang/ produk yang akan ditampilkan oleh para peserta pameran sebagai informasi kepada calon pengunjung.

4) Pengiklanan melalui :

\section{a. Televisi}

Pengiklanan IDA 2008 pada televisi ialah dengan menggunakan iklan slide show yang ditayangkan di Metro TV dan O Channel dan adanya promosi iklan yang dilakukan oleh stasiun televisi swasta lainnya pada peliputan acara IDA berlangsung

Jadwal Tayang Iklan Indo Defence \& Aerospace 2008 Ekpo \& Forum pada Televisi.

\begin{tabular}{|l|l|l|l|l|l|}
\hline No & $\begin{array}{l}\text { Stasiun } \\
\text { Televisi }\end{array}$ & $\begin{array}{l}\text { Jam } \\
\text { Tayang }\end{array}$ & Program & $\begin{array}{l}\text { Durasi } \\
\text { (Detik) }\end{array}$ & Tanggal \\
\hline & Metro TV & $\begin{array}{l}07.05- \\
07.30\end{array}$ & $\begin{array}{l}\text { Indonesia This } \\
\text { Morning }\end{array}$ & 15 & $17-22 / 11 / 2008$ \\
\hline & & $\begin{array}{l}18.05- \\
19.00\end{array}$ & Metro Hari ini & 15 & $17-22 / 11 / 2008$ \\
\hline 2 & O Channel & $07.00-$ & $\begin{array}{l}\text { Selamat Pagi } \\
\text { Jakarta }\end{array}$ & 15 & $17-21 / 11 / 2008$ \\
& & 08.00 & $\begin{array}{l}\text { Target \& Strategi vs } \\
\text { Militer }\end{array}$ & 15 & $16,18,21 / 11 / 2008$ \\
& & & & & \\
\hline
\end{tabular}

Sumber : PT Napindo Media Ashatama

\section{b. Radio}

Pemilihan radio sebagai media iklan yang bersifat massal akan tetapi memiliki karakteristik pendengar sehingga dapat menjangkau calon pengunjung yang diinginkan. Media Radio yang dipilih dalam menginformasikan pameran IDA 2008, PT Napindo Media Ashatama memilih radio Pass Fm dengan bentuk iklan yang digunakan yaitu Adlips dan Business Expose.

Jadwal Siar Adlips Indo Defence \& Aerospace 2008 Expo \& Forum.

\begin{tabular}{|l|l|l|l|l|l|l|l|l|l|}
\hline TIME & \multicolumn{1}{l|}{ NOVEMBER } \\
\hline & 13 & 14 & 15 & 16 & 17 & 18 & 19 & 20 & 21 \\
\hline $08.00-09.00$ & $\mathrm{X}$ & $\mathrm{X}$ & & & $\mathrm{X}$ & $\mathrm{X}$ & & $\mathrm{X}$ & $\mathrm{X}$ \\
\hline $11.00-12.00$ & $\mathrm{X}$ & $\mathrm{X}$ & & & $\mathrm{X}$ & $\mathrm{X}$ & & $\mathrm{X}$ & $\mathrm{X}$ \\
\hline $16.00-17.00$ & $\mathrm{X}$ & $\mathrm{X}$ & & & $\mathrm{X}$ & $\mathrm{X}$ & & $\mathrm{X}$ & $\mathrm{X}$ \\
\hline $17.00-18.00$ & $\mathrm{X}$ & $\mathrm{X}$ & & & $\mathrm{X}$ & $\mathrm{X}$ & & $\mathrm{X}$ & $\mathrm{X}$ \\
\hline $18.00-19.00$ & $\mathrm{X}$ & $\mathrm{X}$ & & & $\mathrm{X}$ & $\mathrm{X}$ & & $\mathrm{X}$ & $\mathrm{X}$ \\
\hline TOTAL & $30 \mathrm{x}$ siar & \multicolumn{7}{|l|}{} \\
\hline
\end{tabular}

Sumber : PT Napindo Media Ashatama

Berdasarkan tabel diatas, pengiklanan radio dalam bentuk Adlips disiarkan sebanyak 30 kali selama enam hari mulai dari tanggal 13-21 November 2008.

Pada bentuk promosi Business Expose PT Napindo Media Ashatama melakukan acara talk show selama satu jam dari pukul 17.00-18.00 WIB, pada tanggal 13 November 2008. Melalui media ini pendengar dapat berdialog secara langsung (on air) dengan Herman Wiriadipoera dari pihak penyelenggara IDA 2008.

\section{c. Situs Internet}

Internet salah satu media efektif, dalam mengiklankan IDA 2008 dan dapat mudah diakses oleh calon pengunjung baik dalam maupun luar negeri. Oleh karena itu, 
desain web IDA 2008 selalu menampilkan perkembangan/ informasi terbaru yang terjadi dan memudahkan calon pengunjung untuk mendaftarkan diri sebagai pengunjung IDA 2008 secara on-line melalui situs www.indofence.com. Selain situs tersebut pihak PT Napindo Media Ashatama pun bekerjasama dengan online publications di antaranya ASD- Network dan ASD Wire.

\section{d. Surat Kabar}

Dalam pemakaian promosi iklan melalui surat kabar, PT Napindo Media Ashatama telah terlebih dahulu menyeleksi dan meilih surat kabar yang akan digunakan. Pemilihan dilakukan oleh divisi marketing komunikasi dan promosi dengan melihat jangkauan dan keboanafitan surat kabar tersebut. Jadwal rencana pengiklanan IDA 2008 pada surat kabar pun dimulai pada bulan Oktober 2008- November 2008 dengan menggunakan surat kabar nasional yang telah diseleksi yaitu: Kompas, Suara Merdeka, Jakarta Post, Media Indonesia dan Bisnis Indonesia, sedangkan untuk surat kabar lokal adaalah Jawa Pos, Pikiran Rakyat, Samarinda Pos, Fajar dan Analisa. Bentuk iklan yang digunakan adalah iklan display dan iklan advetorial, seluruh iklan pada surat kabar ditampilkan dengan warna hitam putih. Jadwal penayangan iklan pada media surat kabar dapat dilihat pada lampiran 9, sedangkan untuk melihat bentuk surat kabar dapat dilihat pada lampiran 10 dan 11.

\section{e. Majalah}

PT Napindo Media Ashatama melakukan kerjasama media dalam pengiklanan IDA 2008 di majalah sebagai media partner. Pengiklanan melalui majalah lebih ditujukan kepada sasaran calon peserta dan pengunjung luar negeri. Desain iklan IDA 2008 yang terdapat pada majalah berbeda dengan desain yang berbeda dengan desain iklan yang ada di koran. Iklan pada majalah memakai gambar alat pertahanan serta terdapatnya kupon untuk turut dalam kepesertaan IDA 2008 dan ditampilkan dengan full colour. PT Napindo Media Ashatama juga memilih majalah yang terkait dengan pertahanan, contohnya : majalah Kanwa Asian Defence, B3n3t, Tempur, Take off, Naval forces, Angkasa, Commando, dan sebagainya

\section{f. Pemasangan Spanduk, Umbul-Umbul, dan Giant Banner.}

PT Napindo Media Ashatama melakukan pemasangan spanduk sebanyak 50 buah, umbul-umbul sebanyak 50 buah dan vertical banner sebanyak 50 buah. Ketiga alat promosi tersebut dipasang pada sudut jalan yang menuju lokasi event dan di tempat strategis yang mudah dibaca oleh publik mulai dari tanggal 16-22 November 2008.

\section{g. Pemasangan Poster}

Poster digunakan untuk menginformasikan adanya pelaksanaan IDA 2008. Poster sendiri dibagikan kepada departemen terkait seperti departemen pertahanan, lembaga pendidikan sekolah/ universitas, dan sebagainya.

Berdasarkan pelaksanaan kegiatan promosi iklan diatas, dapat dianalisis bahwa terdapat cara yang khusus dilakukan oleh PT Napindo Media Ashatama dalam mengirimkan brosur kepada calon pengunjung pameran sehingga brosur tersebut tidak dianggap remeh oleh penerima. Dalam pengiriman brosur secara bertahap yaitu sebanyak dua kali dalam bentuk show update dan show preview dimana hal ini berfungsi untuk mengingatkan (awareness) serta yang membuat menarik adalah dilampirkannya undangan ke pameran IDA 2008 yang bisa membuat calon pengunjung dihargai 


\section{KEGIATAN MEDIA RELATION OFFICER di MARGO CITY DEPOK}

Kegiatan utama yang dijalankan Media Realtion Officer dalam Advertising \& Promotion Department di Margo City Depok, yaitu :

1. Hubungan Media

Sebagai Media Relation Officer dari sebuah mall terbesar di Depok dengan target midle up, sangatlah penting menjalin hubungan baik dengan media. Media Relation Officer menyusun siaran pers (press release) menangani wawancara dengan media massa dan segala hal yang berhubungan dengan media. Margfo City Depok masih membutuhkan media massa untuk melakukan promosi. Hal tersebut dapat terlihat dari seringnya media relation officer bekerjasama dengan media massa seperti melakukan kerjasama dalam pelaksanaan acara yang bertempat di Margo City.

2. Website dan SMS Blast

Untuk memenuhi kebutuhan informasi pelanggan mengenai promosi tenant ataupun aktivitas Margo City. Margo City Depok menyediakan website (www.margocity.com) MS Blast. Dalam pengelolaan website, Media Relation Officer menyiapkan materi untuk diperbarui setiap bulannya dengan bekerjasama dengan IT \& Web Staff untuk menampilkannya di website, sedangkan pengelolaan SMS Blast, Media Relation Officer bekerjasama dengan jasa pengiriman SMS melalui telepon seluler yang dikelola oleh Jatis Mobile.

3. Majalah Internal

Selain website dan sms blast, pelanggan juga bisa mendapatkan informasi mengenai kegiatan dan fasilitas Margo City, tenant Margo City serta berbagai liputan media menarik melalui Margo City Magazine yang diterbitkan setiap tiga bulan sekali. Media Relation Officer Margo City turut andil dalam pembuatan majalah seperti bekerjasama dengan publisher dalam menentukan tema, edit content dan mengatur serta mengontrol pendistribusian majalah tersebut ke perkantoran-perkantoran dan di dalam Margo City itu sendiri untuk didistribusikan ke pengunjung.

Konsep majalah Margo adalah majalah family dan lifestyle dengan menampilkan infomasi-informasi terbaru dan terhangat seputar internal maupun eskternal Margo City. Informasi yang disajikannya pun beraneka ragam, baik itu tentang fashion, trend, sport, entertainment, campus, community, profil artis maupun tokoh masyarakat, event, promosi, kuis dan tidak mengandung unsur-unsur yang melanggar norma kesusilaan maupun SARA (Suku, Agama, Ras, Antar Golongan). Target pembaca majalah Margo adalah keluarga dan mahasiswa yang tinggal di sekitar Depok dan sekitarnya. Free Magazine Margo City setiap tiga bulan sekali dengan jumlah seribu buku setiap edisi.

Tujuan dari free magazine Margo City adalah :

1) Memberikan informasi kepada target audience tentang :

2) Promosi Margo City maupun tenant

3) fasilitas-fasilitas yang terdapat di Margo City

4) Kegiatan acara apa saja yang telah diselenggarakan di Margo City

5) Produk dan tenant baru di Margo City 
6) Menciptakan ketertarikan dan loyalitas target audience untuk selalu dan berbelanja di Margo City melalui informasi yang ditampilkan dalam free magazine tersebut

7) Meningkatkan brand awareness perusahaan

8) Reminder sehingga dapat memperkuat brand image Margo City

9) Menjangkau target audience yang lebih luas lagi

4. Dokumentasi dan Kliping

Media relation officer selalu mendokumentasikan setiap acara yang terselenggara oleh kerjasana antara Margo City dengan pihak media, baik media cetak maupun media elektronik. Dokumentasi tersebut biasanya berupa foto-foto kegiatan yang dilakukan. Selain itu mendokumentasikan kegiatan lain yang dilakukan Media Relation Officer adalah kliping. Kliping merupakan kegiatan dalam memilih, menggunting dan menyimpan setiap berita, artikel serta foto berita yang diterbitkan oleh media cetak. Kegiatan dokumentasi dan kliping memiliki tujuan yaitu sebagai rujukan penting ataun informasi yang diperlukan untuk membuat rencana program kerja berikutnya.

5. Mengelola Media Promosi Outdoor dan Indoor Margo City

Media relation officer Margo City juga berperan dalam pengelolaan media promosi outdoor dan indoor Margo City sepetrti pengaturan jadwal, penentuan harga dan pemberian ijin. Media promosi outdoor yaiotu baliho, mini baliho dan vertical banner. Sedangkan media promosi indoor yaitu poster, banner, penyebaran fliyers di dalam gedung dan paging announcement.

Berdasarkan kegiatan utama tersebut nampak terlihat bahwa kegiatan yang dilakukan oleh Media Relation Officer dalam Advertising \& Promotion Department bertujuan untuk mendukung promosi, peningkatan pendapat tenant dan peningkatan jumlah penyewa di Margo City.

\section{SIMPULAN DAN SARAN}

\section{SIMPULAN}

Secara keseluruhan simpulan yang dapat diambil adalah sebagai berikut :

1. Kegiatan media relation officer dalam penyelenggara sebuah event adalah dengan menyiapkan segala hal yang berkaitan dengan media, seperti menyusun database media, menentukan media yang tepat bagi event-nya, menyiapkan pertemuan dengan media, menyiapkan acara-acara event yang perlu disampaikan untuk dipublikasikan ke media.

2. Strategi Media Relation Officer dalam meraih dukungan publik adalah dengan secara terus menerus memberitakan ke publik tentang acara-acara event yang akan diselenggrakannya. Hal ini dapat dilakukan dengan memasang iklan, mengadakan jumpa pers, menulis advetorial, mengontak wartawan untuk melakukan kunjungan serta melakukan wawancara khusus.

3. Media Relations Officer merupakan bagian dari bidang Public Relations. Peran dan kegiatan yang dilakukan oleh Media Relation Officer secara langsung akan mempengaruhi keberhasilan Public Relations itu sendiri. Demikian pula halnya dengan semua permasalahn yang dialami Media Relation Officer, merupakan juga permasalahan yang dialami public relations. Untuk itu perlu dibangun komunikasi dengan media atau pers. Dengan demikian permasalahan yang dihadapi, jika 
dipublikasikan media tidak akan menjadi negatif dan menimbulkan sensasional. Hubungan yang baik dengan media perlu dijalin dan dijaga dengan baik untuk menjaga pemberitaan yang berimbang dan akurat. Kegiatan yang dapat dilakukan dengan pihak media antara lain adalah, sering mengundang media untuk menghadiri sekaligus meliput berbagai acara, ataupun melakukan kunjungan biasa.

\section{SARAN}

Saran-saran yang perlu diperhatikan oleh Media Relation Officer dalam menyelenggarakan suatu event adalah sebagai berikut :

1. Dalam melaksanakan perannya Media Relations Officer harus memiliki pengetahuan komunikasi terutama komunikasi dengan media, termasuk pula kemampuan teknis untuk bekerjasama dengan media, seperti kemampuan menulis press release maupun advetorial.

2. Media Relation Officer harus pula memiliki kemampuan untuk menjalin hubungan bnaik dengan media, karena kerjasama dalam penyelenggaraan event tidak hanya sekali saja, melainkan akan terus berlangsung.

3. Media Relation officer juga harus selalu mengawasi perkembangan media, menganalisis berita, serta mengembangkan kemampun bernegosiasi unutk membangun kepercayaan dari media.

4. Dalam melaksanakan pemasangan iklan dan advetorial pada media, Media Relation Officer harus mampu membuatnya semenarik mungkin, agardapat menari minat pembaca.

5. Pembuatan dan penyebaran kuesioner unutk mengetahui data dan minat pengunjung perlu dilakukan oleh Media Relation Officer. Hal ini untuk mengetahui kesan saat berkunjung, karena hasil kuesioner tersebut akan dapat digunakan untuk meningkatkan dan menyempurkanan penyelenggaran event di masa mendatang.

\section{DAFTAR PUSTAKA}

Abdullah, Iqbal. A, 2006, Manejemen Konferensi dan Event, INCCA Institute, Jakarta.

Barwise, (2007), Pattern of Public Relations, Journal of Public Relations.

Evelina, Lidia, 2005, Event Organizer Pameran, PT. Indeks, Jakarta

Hutabarat, Arifin, (2001), Praktek Public Relations dan Menulis Untuk PR, Ganesia PR, Jakarta.

Iriantara, Yosal, 2005, Media Relations Konsep, Pendekatan dan Praktik, Simbiosaiosa Rekatam media, Bandung.

Jefkins, Frank, (2004), Public Relations untuk Bisnis - ed. terjemahan, Lembaga PPM dan PT. Pustaka Binaman Pressindo, Jakarta.

Moleong, Lexy.J, (2003), Metodologi Penelitian Kualitatif, Remaja Rosdakarya, Bandung.

Mulyana, Deddy, (2001), Metode Penelitian Kualitatif, Ramaja rosdakarya, Bandung. Rachmad, Jalaludin, (1997), Metode Penelitian Komunikasi, Remaja Rosdakarya, Bandung.

Rachmadi, F, (2004), Public Relations Dalam Teori dan Praktek, PT. Gramedia Pustaka Utama, Jakarta.

Ruslan, Rosady, (2000), Praktik dan Solusi Public Relations, Ghalia Indonesia, Jakarta 
